\title{
Biorefinery Sustainability
}

\section{Assessment}

\author{
Joshua A. Schaidle, Christopher J. Moline, and Phillip E. Savage
}

Department of Chemical Engineering, University of Michigan, Ann Arbor, MI 48109; psavage@umich.edu (for correspondence)

Published online 9 November 2010 in Wiley Online Library (wileyonlinelibrary.com). DOI 10.1002/ep.10516

This article presents a comparative sustainability assessment of three biorefineries that produce liquid fuels used in current infrastructure. The three options considered are biochemical production of ethanol from grain and from cellulosic feedstocks and thermochemical production of Fischer-Tropsch diesel from biomass-derived syngas. These biorefineries were compared using numerous environmental, economic, and social metrics, with numerical values derived from a thorough review of recent literature. For each of the three biorefinery options, the metrics were not determined from a specific process design, but from a variety of different designs reported in literature. Where necessary, corn was selected as the feedstock for grain ethanol and switchgrass was selected for cellulosic ethanol and Fischer-Tropsch diesel. These sustainability metrics were used in an Analytic Hierarchy Process decision analysis to compare the sustainability of the different biorefineries. Thus, a new decision-making tool has been created in which the user can assign different weights to each category and its metrics. This tool was used to explore the influence of different weights, different market conditions, and uncertainties in the values of the metrics on the relative sustainability of the different options. Based on the results of this assessment, cellulosic ethanol biorefineries are modestly more sustainable than grain ethanol and Fischer-Tropsch diesel. Grain ethanol was favorable economically whereas FischerTropsch diesel had the highest score on the societal metrics. (C) 2010 American Institute of Chemical Engineers Environ Prog, 30: 743-753, 2011

Keywords: alternative energy, biofuels, analytic hierarchy, ethanol, Fischer-Tropsch diesel

\section{INTRODUCTION}

Biomass is a renewable resource for sustainable production of fuels, chemicals, and power. Different

(C) 2010 American Institute of Chemical Engineers technologies exist for biorefineries, which are facilities that integrate biomass conversion processes and equipment to produce fuels, power, and chemicals [1]. The objectives of this work were to assess and compare the sustainability of different biorefineries, including both thermochemical and biochemical conversion processes and processes that made fuel from just selected portions of the biomass feedstock and also from entire plants. These objectives were met by focusing on grain ethanol (GE), cellulosic ethanol (CE), and Fischer-Tropsch diesel (FTD) biorefineries. Of course this set of three is not unique, and other choices could have been made. The next section gives descriptions and process flow diagrams for each of these biorefineries.

There have been previous assessments of these biorefineries, with published work ranging from fuel life cycle assessments to economic analyses. The present study builds on and significantly broadens this previous work by presenting a comparative sustainability assessment that employs the triple-bottomline approach (environmental, economic, and social metrics). Moreover, the Analytical Hierarchy Process (AHP), combined with a sensitivity analysis, was used to provide a quantitative comparison of the different biorefineries.

\section{BACKGROUND}

\section{Biorefinery Descriptions}

Grain Ethanol Biorefinery

The dry mill GE process is a well-developed technology for converting corn starches into ethanol. Process steps (illustrated in Figure 1, detailed in Ref. 2) include cleaning and milling of the corn, liquefaction and saccharification to release sugars, fermentation to produce ethanol, and then distillation and drying to produce ethanol and distillers dried grains and solubles (DDGS), a by-product useful as an animal feed [2]. Most current GE producers use electricity from 


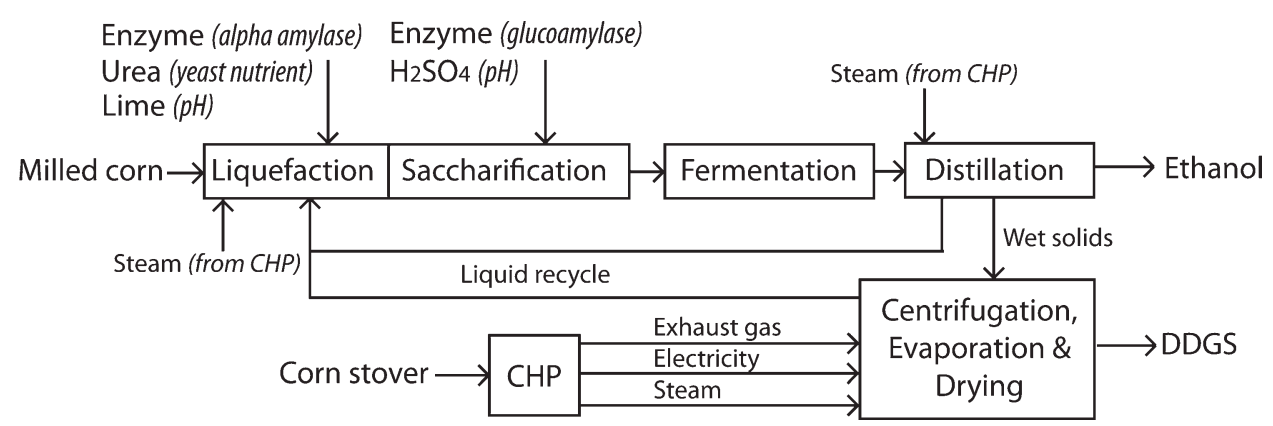

Figure 1. Process flow diagram for GE biorefinery.

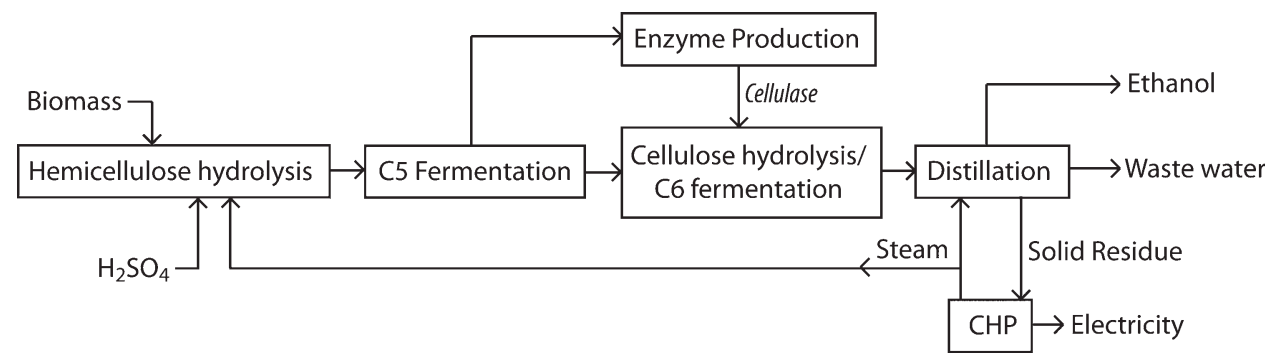

Figure 2. Process flow diagram for CE biorefinery.

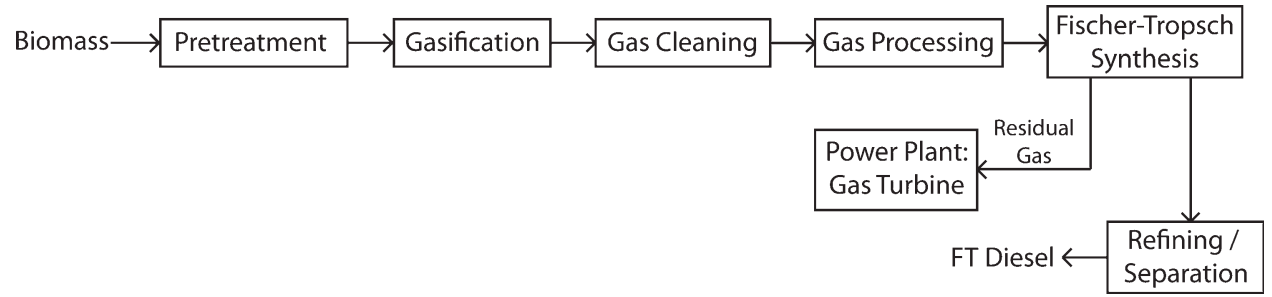

Figure 3. Process flow diagram for FTD biorefinery with gas turbine combined power cycle.

the grid and natural gas for process heat. New stateof-the-art plants are opting for combined heat and power (CHP) systems, which can increase plant energy efficiency by $25 \%$ [3]. Coal or natural gas is typically the CHP fuel source [3], but biomass could also be used.

\section{Cellulosic Ethanol Biorefinery}

The technology to produce ethanol from cellulosic material is more complex and less mature than starch ethanol technology, and different processes have been reported. One of the more common processes is Simultaneous Saccharification and Fermentation (SSF) (illustrated in Figure 2, detailed in Ref. 4). SSF pretreats the feedstock with dilute acid to hydrolyze the sugars in hemicellulose and modify the cellulose structure. The five-carbon sugars liberated from hemicelluloses are then fermented. Next, cellulase enzymes are added to liberate glucose monomers from cellulose while the glucose is actively fermented. The final fermentation product is then dis- tilled to recover the ethanol. Residual solid matter (lignin) is removed and can be used in CHP systems.

\section{Fischer-Tropsch Diesel Biorefinery}

A FTD biorefinery produces diesel fuel via gasification of biomass to make a $\mathrm{CO} / \mathrm{H}_{2}$ mixture, which is then catalytically converted into hydrocarbons of variable chain length (Eq. 1) [5].

$$
(2 n+1) \mathrm{H}_{2}+n \mathrm{CO} \rightarrow C_{n} \mathrm{H}_{2 n+2}+n \mathrm{H}_{2} \mathrm{O}
$$

A variety of process configurations are possible, but all of them include the six steps shown in Figure 3: pretreatment, gasification, gas cleaning, gas processing, Fischer-Tropsch Synthesis (FTS), and fuel refining/separation. The primary function of the pretreatment step is to dry the biomass to improve the efficiency of the gasifier [6]. The gasifier produces synthesis gas $\left(\mathrm{H}_{2} / \mathrm{CO}\right.$ mixture) along with other gases and contaminants, such as alkali compounds, $\mathrm{H}_{2} \mathrm{~S}$, $\mathrm{HCl}, \mathrm{NH}_{3}, \mathrm{HCN}$, and COS. These contaminants can 


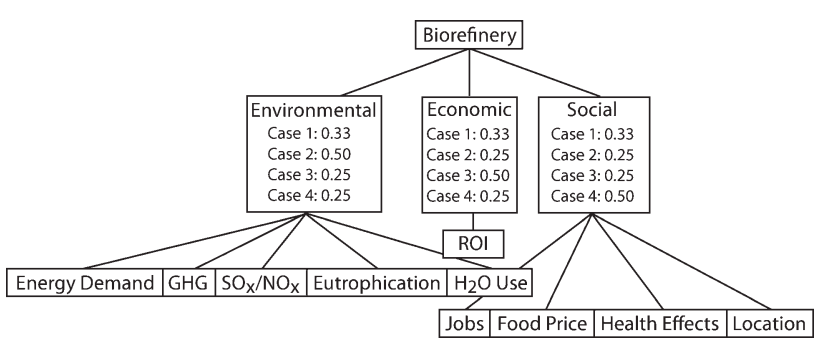

Figure 4. The hierarchy tree used in the AHP analysis for biorefinery selection.

poison the FTS catalyst, so they are reduced to acceptable levels [7] during the gas cleaning step. Final processing steps (methane steam reforming, the water gas shift reaction, and $\mathrm{CO}_{2}$ removal) may be necessary before the synthesis gas enters the FTS reactor. The last step in the process is refining or upgrading the hydrocarbon effluent from the FTS reactor to produce diesel fuel (primarily $\mathrm{C}_{10}-\mathrm{C}_{15}$ hydrocarbons) [8].

\section{Analytic Hierarchy Process Methodology}

The Analytic Hierarchy Process (AHP) is a decision-making tool that can incorporate the many competing factors involved in answering a complex question [9, 10]. The process involves creating a hierarchy containing a goal (e.g., sustainable production of liquid fuel from biomass), evaluation criteria and subcriteria, and alternative means of meeting the goal (e.g., GE, CE, FTD). Each criterion is weighted, based on its importance, and the sum of the weights are normalized to unity. For each criterion, the alternative solutions are assigned scores based on quantitative or qualitative considerations. The decision outcome is then determined by the weight placed on each criterion and the numerical scores assigned to each alternative.

AHP was used to assess the sustainability of the different biorefineries based on environmental, economic, and social impacts. These triple bottom line criteria form the first tier of the hierarchy [11, 12]. Some of the criteria were further divided into subcriteria as shown in Figure 4. These subcriteria will be discussed in detail in the Sustainability Evaluation section.

In the base case analysis, the environmental, economic, and social impacts were weighted equally. This choice was arbitrary; different people may have different judgments, therefore other weightings were also explored. Three additional perspectives were considered in which one criterion was given twice the priority of the other two. Subcriteria were weighted equally in every case for simplicity. A sensitivity analysis was also performed by varying subcriteria scores within the range reported in literature for each biorefinery alternative.

The Sustainability Evaluation section presents subcriteria values for each biorefinery alternative. In most cases, lower values are better (e.g. all emissions); however, return on investment (ROI) and job
Table 1. $E_{\text {total }}$ values for GE, CE, and FTD biorefineries.

\begin{tabular}{lcc}
\hline & \multicolumn{2}{c}{$\boldsymbol{E}_{\text {total }}$} \\
\cline { 2 - 3 } Biorefinery type & Literature & AHP input \\
\hline GE & $2.3[13], 2.15[14]$ & 2.23 \\
CE & $2.13[13], 2.05[14]$ & 2.09 \\
FTD & $2.3[14], 2.2-2.3[15]$ & 2.25 \\
& \\
\hline
\end{tabular}

creation are exceptions. In the AHP Results section, higher values indicate better performance in all cases.

In the interest of clarity, supplementary material is available. It provides sample calculations and the spreadsheet used to perform the AHP analysis.

\section{SUSTAINABILITY EVALUATION}

This section presents the values for the environmental, economic, and social metrics for each of the three biorefinery alternatives. For the environmental and social metrics, these values were not based on a specific process design; they were determined from reported values in literature based on a variety of process designs and feedstocks. In most cases, the AHP input value was selected by taking an average of the highest and lowest values in the range of reported values. Where necessary, such as for the potential for eutrophication metric, the feedstocks were selected to be corn for GE and switchgrass for $\mathrm{CE}$ and FTD. For the economic metric, calculations were based on a specific process design for each biorefinery alternative.

\section{Environmental Metrics}

Energy demand, Greenhouse gas (GHG) emissions, $\mathrm{SO}_{\mathrm{x}}$ and $\mathrm{NO}_{\mathrm{x}}$ emissions, potential for eutrophication, and water use are the environmental metrics considered in this study. The functional unit was 1 MJ of biofuel produced by the biorefinery and subsequently combusted in a vehicle. All parameters reported in this section correspond to the use of $100 \%$ ethanol as fuel. Data from studies that used E85 (85\% ethanol-15\% gasoline mixture by volume) was converted to a $100 \%$ ethanol basis by assuming that gasoline contributes $15 \%$ to the reported value and ethanol contributes $85 \%$. The choice to weight based on volume percent was arbitrary; one could also weight based on heating value. The energy densities used in this study for gasoline, ethanol, and FTD were 44,27 , and $41 \mathrm{MJ} / \mathrm{kg}$, respectively.

\section{Energy Demand}

The energy efficiency and consumption of fossil fuels for GE, CE, and FTD biorefineries were compared using the ratio of well-to-wheel (WTW) total energy input to energy in the fuel $\left(E_{\text {total }}\right)$ and the ratio of WTW total fossil fuel energy input to energy in the fuel $\left(E_{\text {fossil }}\right)$. Life-cycle assessments (LCA) of GE, $\mathrm{CE}$, and FTD using the Greenhouse gases, Regulated Emissions, and Energy use in Transportation model developed by Argonne National Lab (GREET) [13-15] provide data that led to the $E_{\text {total }}$ values in Table 1. 
Table 2. $E_{\text {fossil }}$ values for GE, CE, and FTD biorefineries.

\begin{tabular}{lcc}
\hline \multirow{2}{*}{$\begin{array}{l}\text { Biorefinery } \\
\text { type }\end{array}$} & \multicolumn{1}{c}{$\boldsymbol{E}_{\text {fossil }}$} \\
\cline { 2 - 3 } & Literature & AHP input \\
\hline GE & 0.33 to $0.42[13]$ & 0.38 \\
GE & $0.09[13], 0.08[14]$, & 0.11 \\
& -0.01 to $0.15[20], 0.13[23]$ & \\
FTD & $0.07[14], 0.1$ to $0.22[15]$, & 0.14 \\
& $0.14[23], 0.05$ to $0.14[24]$ & \\
& & \\
\end{tabular}

The GREET model evaluates energy consumption, GHG emissions, and pollutant emissions over the entire life-cycle of a fuel (well-to-wheel). It takes into account production, transportation, distribution, and storage of both the feedstock and the fuel, as well as fuel combustion, fuel evaporation, and vehicle refueling.

The $E_{\text {total }}$ value calculations used the lower heating value of the fuel, and the total energy input accounted for all energy sources including fossil and renewable energy (energy embedded in corn kernels and biomass). Additionally, CHP systems fueled by biomass were employed at the biorefineries. Overall, the $E_{\text {total }}$ values are very similar for all three biorefineries but higher than the $E_{\text {total }}$ for gasoline of 1.25 [13-15].

There has been considerable debate over the $E_{\text {fossil }}$ value for GE produced from corn. A number of early LCA studies concluded that $E_{\text {fossil }}$ for GE was greater than 1 [16-19], while some of the more recent LCA studies have reported GE $E_{\text {fossil }}$ values in the range of 0.5 to $0.8[13,14,20-22]$. The large disparity in LCA results is due to varying system boundaries, coproduct energy allocation procedures, and accuracy of input data.

One particular study performed a fuel LCA of GE produced from corn as well as CE and FTD produced from switchgrass using GREET and Aspen [23]. The values for WTW fossil energy input were reported relative (as a percentage) to gasoline or diesel. However, the absolute values for gasoline and diesel were not given in the article, making it difficult to compare their values with literature. To solve this problem, we simulated the fuel life-cycle for gasoline and diesel using GREET version $1.8 \mathrm{~b}$ along with the same assumptions used in the article. From the simulation, it was determined that the $E_{\text {fossil }}$ values for gasoline and diesel were 1.21 and 1.05 , respectively, which fall within the range reported in literature [15]. Based on these values for gasoline and diesel, the $E_{\mathrm{fossil}}$ values for GE, CE, and FTD would be 1.03, 0.13, and 0.14 , respectively [23]. However, this report considered CE and FTD biorefineries that incorporated CHP systems fueled by biomass residuals whereas the GE biorefinery did not, thus making for a biased comparison [23]. Corn stover or distiller dried grains and solubles (DDGS) could be used to fuel a CHP system $[13,21]$ in a GE biorefinery. Wang et al. found that $E_{\text {fossil }}$ for a GE biorefinery drops from 0.76 to
Table 3. Fuel life cycle GHG emissions for GE, CE and FTD biorefineries.

\begin{tabular}{lcc}
\hline \multirow{2}{*}{$\begin{array}{l}\text { Biorefinery } \\
\text { type }\end{array}$} & \multicolumn{2}{c}{$\begin{array}{c}\text { GHG emissions } \\
\text { (g CO } \mathbf{2} \text { eq./MJ of biofuel) }\end{array}$} \\
\cline { 2 - 3 } GE & Literature & AHP input \\
CE & 44 to $57[13]$ & 51 \\
& $12[13],-9[14]$, & 7 \\
FTD & $-5[20], 23[23], 11[27]$ & \\
& $11[14],-5$ to $19[15]$, & 22 \\
& $7[23], 18$ to $48[24]$ \\
\hline
\end{tabular}

0.42 with CHP using DDGS and to 0.33 using corn stover [13].

Table 2 shows $E_{\text {fossil }}$ values for GE, CE, and FTD biorefineries that were calculated from a number of published sources. It also shows the representative values selected for this analysis. Negative $E_{\text {fossil }}$ values occur when electricity co-produced from biomass residuals at the biorefinery displace electricity from the grid produced from fossil fuels. The amount of electricity produced at the biorefinery has a strong effect on $E_{\text {fossil }}$. CE and FTD require the least amount of fossil energy input throughout the fuel life-cycle.

\section{Greenhouse Gas Emissions}

In this section, the global warming potential of GE, CE, and FTD biorefineries was assessed by comparing fuel life-cycle GHG $\left(\mathrm{CO}_{2}, \mathrm{CH}_{4}\right.$, and $\left.\mathrm{N}_{2} \mathrm{O}\right)$ emissions in terms of grams of $\mathrm{CO}_{2}$-equivalent per $\mathrm{MJ}$ of biofuel. To determine GHG emissions in terms of grams of $\mathrm{CO}_{2}$-equivalents, the emissions of $\mathrm{CO}_{2}, \mathrm{CH}_{4}$, and $\mathrm{N}_{2} \mathrm{O}$ were weighted by their 100-yr global warming potentials set by the IPCC ( 1 for $\mathrm{CO}_{2}, 23$ for $\mathrm{CH}_{4}$, and 296 for $\mathrm{N}_{2} \mathrm{O}$ ).

From the GREET simulation and the report by Wu et al., the fuel life-cycle GHG emissions for GE, CE, and FTD were calculated to be 99,23 , and $7 \mathrm{~g} \mathrm{CO}_{2}$ eq./MJ of biofuel, respectively [23]. The GE value does not include a CHP system at the GE biorefinery, which would significantly reduce GHG emissions [3, $25,26]$. For a GE biorefinery incorporating a biomassfueled CHP system, GHG emissions fall in the range of 44 to $57 \mathrm{~g} \mathrm{CO}_{2}$ eq./MJ [13]. Table 3 shows the fuel life-cycle GHG emissions reported from a number of studies for biorefineries equipped with biomassfueled CHP systems, along with the values selected for AHP input.

\section{$\mathrm{SO}_{x}$ and $\mathrm{NO}_{x}$ Emissions}

$\mathrm{SO}_{\mathrm{x}}$ and $\mathrm{NO}_{\mathrm{x}}$ emissions for GE, CE, and FTD reported in literature are shown in Table 4. Calculated $\mathrm{SO}_{\mathrm{x}}$ and $\mathrm{NO}_{\mathrm{x}}$ emissions depend strongly on the assumed electricity mix, the amount of fertilizer needed for growing corn or cellulosic feedstocks such as switchgrass, CHP systems and the amount of electricity exported, and manufacturing of farm equipment. Thus, evaluating $\mathrm{SO}_{\mathrm{x}}$ and $\mathrm{NO}_{\mathrm{x}}$ emissions within a LCA is subject to greater uncertainties than is estimating energy demand or GHG emissions [13]. 
Table 4. Fuel life cycle $\mathrm{SO}_{\mathrm{x}}$ and $\mathrm{NO}_{\mathrm{x}}$ emissions for GE, CE, and FTD biorefineries.

\begin{tabular}{lcccccc}
\hline & \multicolumn{2}{c}{ SO $_{\mathbf{x}}$ emissions $(\mathbf{g} / \mathbf{M J})$} & & \multicolumn{2}{c}{ NO $_{\mathbf{x}}$ emissions (g/MJ) } \\
\cline { 2 - 3 } Biorefinery type & Literature & AHP input & & Literature & AHP input \\
\hline GE & $0.081[23], 0.055-0.066[28]$ & 0.066 & & $0.25[23], 0.12-0.15[28]$ & 0.12 \\
GE & $0.51[20], 0.014[23]$, & 0.014 & & $0.35[20], 0.15[23]$, & 0.15 \\
FTD & $0.009-0.023[28], 0.22-0.23[29]$ & & & $0.05-0.14[28], 0.63-0.65[29]$ & \\
& $0.009[23], 0.06-0.11[24]$ & 0.009 & & $0.10[23], 0.03-0.07[24]$ & 0.10 \\
\hline
\end{tabular}

Table 5. Nitrogen (N) and phosphorus (P) losses for corn and switchgrass.

\begin{tabular}{|c|c|c|c|c|}
\hline \multirow[b]{2}{*}{ Feedstock } & \multicolumn{2}{|c|}{ N loss } & \multicolumn{2}{|c|}{ P loss } \\
\hline & kg/ha & $\mathrm{kg} / \mathrm{kg}$ feedstock & kg/ha & $\mathrm{kg} / \mathrm{kg}$ feedstock \\
\hline Corn & 30 & $3.3 \times 10^{-3}$ & 9 & $9.9 \times 10^{-4}$ \\
\hline Switchgrass & 9 & $8.5 \times 10^{-4}$ & 3 & $2.8 \times 10^{-4}$ \\
\hline
\end{tabular}

Table 6. Consumptive water use for GE, CE, and FTD biorefineries.

\begin{tabular}{|c|c|c|}
\hline \multirow[b]{2}{*}{ Biorefinery } & \multicolumn{2}{|c|}{$\begin{array}{c}\text { Water use (L } \mathrm{H}_{2} \mathrm{O} / \mathrm{MJ} \text { fuel } \\
\text { produced) }\end{array}$} \\
\hline & Literature & AHP input \\
\hline $\mathrm{GE}$ & $\begin{array}{c}0.16-0.28 \text { [34], } \\
0.14-0.33[35], 0.19[36]\end{array}$ & 0.19 \\
\hline $\mathrm{CE}$ & $\begin{array}{c}0.28[37], 0.09-0.28[36] \\
0.45[38]\end{array}$ & 0.28 \\
\hline FTD & $0.37[39]$ & 0.37 \\
\hline
\end{tabular}

Only Wu et al. performed a LCA for each biorefinery, which allows for a direct comparison [23]. Based on the GREET simulation and their fuel LCA, $\mathrm{SO}_{\mathrm{x}}$ emissions for GE, CE, and FTD were 0.081, $0.014,0.009 \mathrm{~g} / \mathrm{MJ}$ of biofuel, respectively [23]. $\mathrm{NO}_{\mathrm{x}}$ emissions were determined to be 0.25 for GE, 0.15 for $\mathrm{CE}$, and $0.10 \mathrm{~g} / \mathrm{MJ}$ for FTD [23]. Recall, however, that Wu et al. did not incorporate a biomass-fueled CHP system into their GE biorefinery. Doing so could reduce $\mathrm{SO}_{\mathrm{x}}$ emissions by $18 \%$ and $\mathrm{NO}_{\mathrm{x}}$ emissions by $53 \%$ [28]. By including these reductions, the AHP input values for $\mathrm{SO}_{\mathrm{x}}$ and $\mathrm{NO}_{\mathrm{x}}$ emissions were determined and are shown in Table 4.

\section{Eutrophication}

To assess the potential for eutrophication of grainbased and cellulosic-based biofuels, the losses of nitrogen $(\mathrm{N})$ and phosphorus $(\mathrm{P})$ per $\mathrm{kg}$ of feedstock during farming were compared for corn and switchgrass (model cellulosic feedstock). Corn is an inherently inefficient nutrient user with approximately $40 \%$ to $60 \%$ of the $\mathrm{N}$ applied not being taken up by the crop, however, switchgrass is much more efficient due to its extensive root systems [30]. The losses for corn are reported to be 20 to $40 \mathrm{~kg} \mathrm{~N} / \mathrm{ha}$ and 2 to 15 $\mathrm{kg} \mathrm{P} /$ ha [30]. While specific values for $\mathrm{N}$ and $\mathrm{P}$ losses for switchgrass were not found, it is estimated that switchgrass could reduce $\mathrm{N}$ and $\mathrm{P}$ losses by as much as $50 \%$ to $90 \%$ compared with corn [30].

The $\mathrm{N}$ and $\mathrm{P}$ losses for corn and switchgrass are given in Table 5. The losses in $\mathrm{kg} / \mathrm{ha}$ for switchgrass were calculated as 30\% of the values for corn. To normalize the loss values, the average yields for corn and switchgrass for seven Midwest states [31] were used to calculate losses in terms of $\mathrm{kg} / \mathrm{kg}$ feedstock. The average yields were $9120 \mathrm{~kg}$ corn/ha and 10,600 kg switchgrass/ha [31]. Since the mass energy densities of corn and switchgrass are similar [32, 33] and depend highly upon the moisture content, the normalized losses in terms of $\mathrm{kg} \mathrm{N} / \mathrm{kg}$ feedstock and $\mathrm{kg} \mathrm{P} / \mathrm{kg}$ feedstock were used as input for the AHP analysis.

Water Use

Table 6 shows the consumptive water use of GE, $\mathrm{CE}$, and FTD biorefineries. These values correspond to water use by the biorefinery during production of the fuel; they do not include the water consumed while growing the feedstock. Water use values for GE biorefineries come from full-scale operating plants [34]. Since CE and FTD biorefineries are only at the pilot-plant scale, water use values are from simulations and models [37]. The primary water demand for all three biorefineries is for energy production, specifically cooling tower and boiler systems [37, 40]. FTD biorefineries, in addition, consume water during the gasification, gas cleaning, and gas processing steps (Figure 3).

\section{Economic Metric}

Return on investment (ROI) was used as the single economic metric for the AHP analysis since capital cost, operating cost, and fuel sale price each contribute to ROI. The ROI was calculated for each process by updating an economic analysis in the literature [41]. This recent study by Wright and Brown compares the capital and operating costs for different biofuel plants. This study was modified by using updated prices for corn (\$4/bushel), DDGS (\$100/ $\mathrm{Mg})$, and cellulosic feedstock $(\$ 60 / \mathrm{Mg})$ and different 
Table 7. Capital costs, operating costs, and return on investment for GE, CE and FTD biorefineries.

\begin{tabular}{lcccccc}
\hline $\begin{array}{l}\text { Plant } \\
\text { type }\end{array}$ & $\begin{array}{c}\text { Ref plant } \\
\text { size }\left(\mathbf{1 0}^{\mathbf{6}} \mathbf{G J} / \mathbf{y r}\right)\end{array}$ & $\begin{array}{c}\text { Capital scaling } \\
\text { exponent }\end{array}$ & $\begin{array}{c}\text { Plant } \\
\left.\text { size } \mathbf{( 1 0}^{\mathbf{6}} \mathbf{G J} / \mathbf{y r}\right)\end{array}$ & $\begin{array}{c}\text { Capital cost } \\
\text { (millions } \\
\text { of US } \mathbf{~})\end{array}$ & $\begin{array}{c}\text { Operating } \\
\text { cost (US \$/L } \\
\text { gasoline eq.) }\end{array}$ & ROI (\%)* \\
\hline GE & 2.01 & $0.63[2]$ & 12 & 143 & 0.61 & 24.1 \\
CE & 4.03 & $0.63[2]$ & 12 & 585 & 0.53 & 11.1 \\
FTD & 4.79 & $0.91[8]$ & 12 & 786 & 0.54 & 7.9 \\
\hline
\end{tabular}

*A wholesale price for gasoline and diesel of $\$ 0.70 / \mathrm{L}$ was used.

Table 8. Relative number of jobs created by GE, CE, and FTD biorefineries.

\begin{tabular}{lc}
\hline Biorefinery & Relative number of jobs created \\
\hline GE & 1 \\
CE & 2 \\
FTD & 2.5 \\
\hline
\end{tabular}

scaling exponents for capital costs of FTD processes. Wright and Brown [41] used scaling exponents of 0.63 for GE and CE, and 0.70 for FTD, but an analysis of the FTD process [8] reports a higher scaling exponent of 0.91 , indicating less economic benefit from plant scale-up. Additionally, the GE plant was modified with the addition of on-site CHP generation from biomass to reflect the model used throughout this analysis. The capital cost of this addition was estimated using the cost of a new 75 million L/yr (MLY) installation priced at \$14 M [42] and using a scaling exponent of 0.7 . Utility costs were subsequently reduced by $25 \%$ [3]. Using a gasoline and diesel sale price of $\$ 0.70 / \mathrm{L}$ and plant productivities of $1.2 \times 10^{7}$ $\mathrm{GJ} / \mathrm{yr}$ (or $100 \mathrm{M}$ gallons gasoline equivalent), GE had the highest ROI (24.1\%). Table 7 presents a complete summary of the key economic results.

\section{Social Metrics}

\section{Job Creation}

New biofuel plants create jobs at the facility and also through indirect industry and household spending effects. A study of corn ethanol plants in Iowa found that a 380 MLY plant creates 46 jobs directly, 95 jobs indirectly, and 29 jobs via household spending effects [43]. In keeping with this literature, it was assumed that jobs created through indirect industry and household spending effects scale linearly with the number of jobs created at each type of plant [43]. Note that the loss of jobs by displacing petroleum refineries has not been included in this evaluation. Such losses would likely impact all three biorefineries equally.

The relative number of jobs created at each plant depends on the complexity of the production process [44]. A comparison of process flow diagrams and equipment specifications reveals that FTD production is the most complex process, followed by $\mathrm{CE}$ and finally GE $[2,8]$. A report by NREL on the costs of ethanol production from cornstarch and lignocellulose found that a CE plant requires twice the number of shift workers as a corn ethanol plant of the same size [2]. Detailed economic information is not yet available for FTD plants. Comparing the higher economic scaling exponent of large-scale FTD plants (0.91) [8] with that of ethanol plants (0.63) [2], it has been assumed that a FTD plant will employ the number of workers required by a CE plant plus half the number of GE shift workers (Table 8).

\section{Food Price}

Increasing demand for biomass feedstock may have an effect on food prices. GE has received the most criticism in this respect. Ethanol producers demand more than $25 \%$ of the total US corn harvest [45]. The Congressional Budget Office estimates that increases in ethanol production caused $28 \%$ to $47 \%$ of the increase in corn price from April 2007 to April 2008 [45]. It is interesting to note that current government subsidies for GE may have the effect of increasing food costs. In addition, increases in food prices will tend to have the greatest effect on consumption by the poorest demographics since their food choice is highly contingent upon price. Early CE or FTD will likely be produced using by-products such as corn stover or dedicated feedstock grown on marginal land, and therefore will likely have less of an effect on food prices.

Obtaining a quantitative comparison of the food price effects of cellulose- and corn-based biorefineries is challenging since little information is available on the cellulosic feedstock cultivation. It is clear that GE production is causing some increase in food price, and that the cellulosic platform will have a lesser effect on food price. It was assumed that the food price effects of GE production will be twice that of the cellulosic platforms (CE and FTD).

\section{Health Effects}

Throughout the WTW life cycle of liquid transportation fuels, air pollutants are emitted that have harmful human health effects. Three of these major pollutants are particulate matter less than $10 \mu \mathrm{m}$ in diameter (PM-10), carbon monoxide, and volatile organic compounds (VOC). Similar to the case with $\mathrm{SO}_{\mathrm{x}}$ and $\mathrm{NO}_{\mathrm{x}}$ emissions, very few LCA studies in the literature have reported emissions levels for these pollutants due to the lack of accuracy in estimating these values. Therefore, the AHP input for these 
emissions was based on the GREET simulation of the report by Wu et al. [23]. A biomass-fueled CHP system was again incorporated into the GE biorefinery. Implementing such a system could decrease PM-10 emissions by approximately 54\%; however, CO and VOC emissions would remain virtually the same [28]. With this reduction, the ratio of GE PM-10 emissions to CE PM-10 emissions is close to 2, which agrees with the ratio reported by Hill et al. (2.05) [46]. Furthermore, another study has reported similar pollutant emissions values for CE biorefineries [28]. Table 9 gives the values used in the AHP analysis.

\section{Location of Pollutant Emissions}

The location of emissions plays a major role in determining the overall exposure risk. Urban emissions of criteria pollutants such as $\mathrm{CO}, \mathrm{VOC}, \mathrm{SO}_{\mathrm{x}}, \mathrm{NO}_{\mathrm{x}}$, and $\mathrm{PM}$ can be calculated using GREET. Two GREET LCA studies by Wu et al. revealed that urban emissions of these five pollutants are highest for GE followed by CE then FTD [23, 28]. Moreover, Hill et al. investigated the spatial change in atmospheric PM-2.5 concentration across the United States due to producing and using an additional 4 billion L of ethanol [46]. Their results show that CE options have much less of an effect on atmospheric PM-2.5 concentrations than does GE, especially in urban areas. Based on these studies, the overall pollutant exposure risk for each of these biorefineries was

Table 9. PM-10, CO, and VOC emissions for GE, CE, and FTD biorefineries (based on Ref. 23).

\begin{tabular}{lccc}
\hline $\begin{array}{l}\text { Biorefinery } \\
\text { type }\end{array}$ & $\begin{array}{c}\text { PM-10 } \\
(\mathbf{g} / \mathbf{M J})\end{array}$ & $\begin{array}{c}\text { CO } \\
(\mathbf{g} / \mathbf{M J})\end{array}$ & $\begin{array}{c}\text { VOC } \\
(\mathbf{g} / \mathbf{M J})\end{array}$ \\
\hline GE & $0.070(0.032)^{*}$ & 1.66 & 0.10 \\
CE & 0.017 & 1.63 & 0.10 \\
FTD & 0.011 & 1.32 & 0.05 \\
\hline
\end{tabular}

*Value in parentheses corresponds to reduction in PM-10 emissions due to biomass-fueled CHP system.

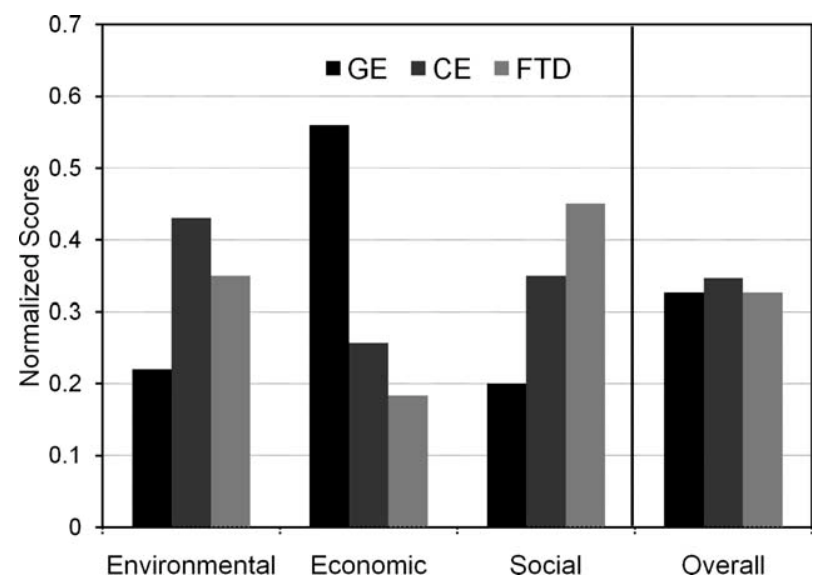

Figure 5. Normalized scores for the environmental, economic, and social impact criteria as well as the overall scores for the base case. evaluated using pair-wise comparisons. It was assumed that the total human exposure risk for GE biorefineries is twice that of CE biorefineries and that FTD biorefineries present 30\% less risk than CE biorefineries.

\section{AHP RESULTS}

Having described the basis for the numerical value of each environmental, economic, and social metric, we next use these values in the AHP assessment. This section presents and discusses the key results.

\section{Base Case}

Figure 5 shows the results from the AHP assessment of the three different biorefineries. In this base case, each aspect of the triple bottom line was equally weighted. The three options have similar overall scores, but CE scores modestly higher than the other two, indicating that of the options investigated and with the metrics used in this report, CE is the most sustainable option. Figure 5 also shows the individual normalized scores for the environmental, economic, and social impact categories.

No one biorefinery option performed best in all of the triple bottom line categories. In fact, each category had a different option as the preferred choice. For the environmental impact category, CE had the highest normalized score (0.43) indicating that it has the smallest impact on the environment. The primary reasons for its high score were high energy conversion efficiency (low total energy and fossil energy inputs) as well as low GHG emissions. Figure 6 provides the details about how each option fared with the different environmental metrics. FTD performed similarly to CE for a number of metrics. However, it was hampered by its high water use at the biorefinery during fuel production as well as having higher energy inputs and GHG emissions than CE. GE received the lowest environmental score (0.22) due to high energy input requirements and high GHG and $\mathrm{SO}_{\mathrm{x}} / \mathrm{NO}_{\mathrm{x}}$ emissions. Moreover, corn has higher $\mathrm{N}$ and $\mathrm{P}$ losses during farming than cellulosic feedstocks such as switchgrass, therefore it has a greater potential for eutrophication. On the other hand, GE biorefineries are more efficient in terms of water use.

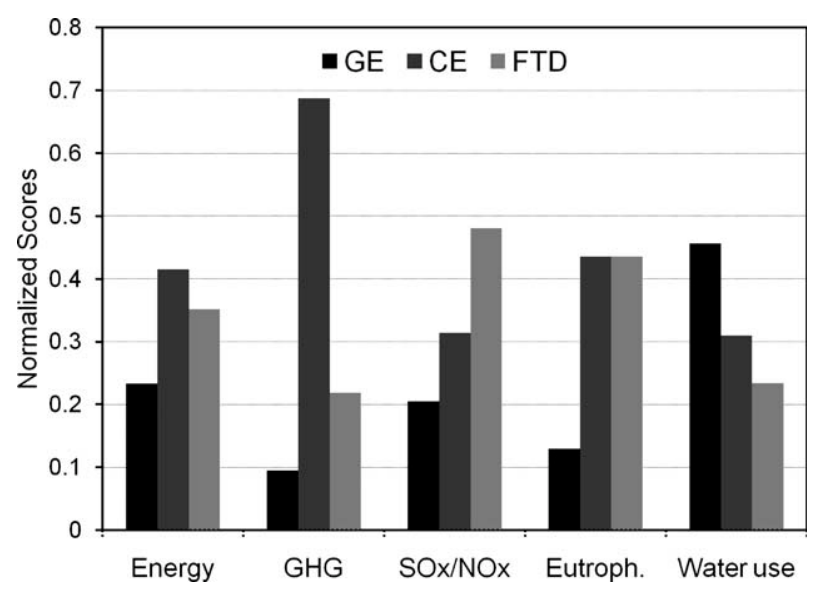

Figure 6. Normalized scores for environmental subcriteria. 


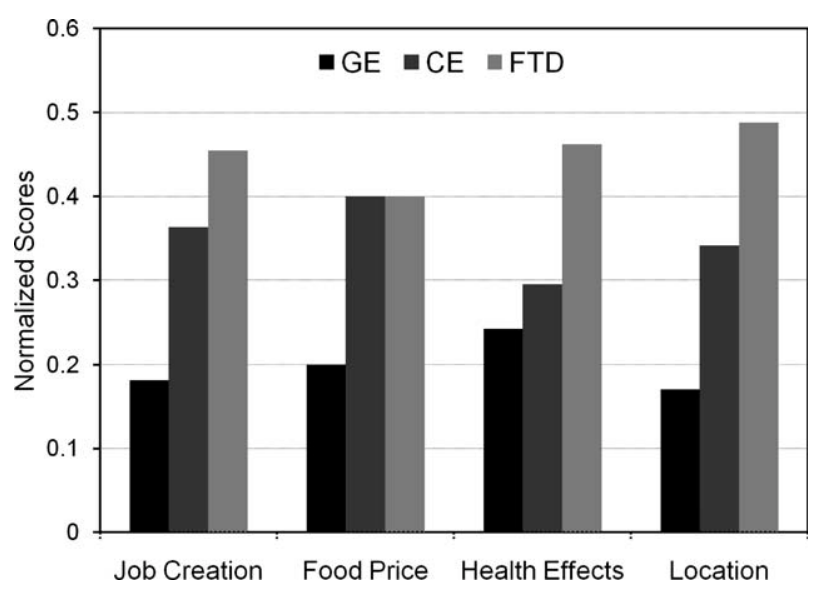

Figure 7. Normalized scores for social subcriteria.

Table 10. Effect of corn price on GE ROI.

\begin{tabular}{lc}
\hline Corn price (US \$/bushel) & GE ROI (\%) \\
\hline 3.00 & 60.7 \\
3.50 & 42.4 \\
4.00 & 24.1 \\
4.50 & 5.8 \\
5.00 & -12.5 \\
5.50 & -30.8 \\
\hline
\end{tabular}

In the economics category, Figure 5 shows that GE had the highest normalized score (0.56). GE has low capital costs and high return on investment. The low capital costs are in part due to the process and technology being well-understood and well-developed. Over time, one would expect that capital costs for CE and FTD biorefineries will decrease due to process/technology improvements. GE was followed by CE (0.26) in second and FTD $(0.18)$ in third. FTD biorefineries were significantly hindered by high capital costs, which arise from the complexity of the process. Operating costs, however, were the lowest for CE and FTD biorefineries due to the relatively low cost of cellulosic feedstock as opposed to corn.

In the societal category, Figure 5 shows that FTD biorefineries $(0.45)$ have the most favorable implications, followed by the $\mathrm{CE}(0.35)$ and $\mathrm{GE}$ biorefineries (0.2). Figure 7 shows details about how each option fared with the different societal impact metrics. FTD has the lowest harmful emissions and uses a nonfood feedstock. Additionally, due to the complexity of the process, a greater number of jobs are created to produce a specific amount of fuel. GE has poor performance across the board in this societal category due to its relatively high emissions and use of a food resource for fuel production.

\section{Sensitivity Analysis}

A sensitivity analysis was performed to assess how strongly the relative rankings of the biorefineries depended on the precise values and weights used in the AHP analysis. The sensitivity was assessed in two ways: (1) individual inputs for the environmental, economic, and social categories were varied and (2)
Table 11. Effect of cellulosic feedstock price on CE and FTD ROI.

\begin{tabular}{lcc}
\hline $\begin{array}{l}\text { Cellulosic feedstock } \\
\text { price (US \$/Mg) }\end{array}$ & $\begin{array}{c}\text { CE } \\
\text { ROI (\%) }\end{array}$ & $\begin{array}{c}\text { FTD } \\
\text { ROI (\%) }\end{array}$ \\
\hline 40 & 17.3 & 11.6 \\
50 & 14.2 & 9.8 \\
60 & 11.1 & 7.9 \\
70 & 7.9 & 6.0 \\
80 & 4.8 & 4.2 \\
90 & 1.7 & 2.3 \\
100 & -1.4 & 0.5 \\
110 & -4.5 & -1.4 \\
\hline
\end{tabular}

multiple decision-making perspectives were evaluated by varying the weightings of the environmental, economic, and social categories. For the analysis of sensitivity to the individual inputs, all values determined from the literature were varied within their ranges reported in literature. For all other metrics save food price, the AHP input values were varied by $\pm 10 \%$. Due to a high degree of uncertainty, the impact of GE on food price was varied from 1.5 to 4 times that of cellulosic platforms, CE and FTD. Each input parameter was varied individually, one at a time.

\section{Individual Inputs}

For the environmental and social categories, no variation of any single parameter within the range studied changed the relative rankings of the biorefineries. This result indicates that the differences between the three biorefineries are significant for these two categories. However, it is important to note that this result can also partly be attributed to the large number of metrics used. The more metrics one uses, the less opportunity there is for any one metric to single-handedly alter the overall outcome.

On the other hand, the economic outcome (ROI) was very sensitive to changes in feedstock prices and fuel sale price. In this study, corn was priced at $\$ 4.00 /$ bushel, cellulosic feedstock at $\$ 60 / \mathrm{Mg}$, and gasoline at $\$ 0.70 / \mathrm{L}$. The sensitivity of ROI is apparent when varying these parameters individually. Raising the corn price to $\$ 4.36 /$ bushel results in equal ROI for $\mathrm{GE}$ and $\mathrm{CE}$ of $11.1 \%$. Lowering cellulosic feedstock to $\$ 18 / \mathrm{Mg}$ results in equal $\mathrm{ROI}$ for $\mathrm{GE}$ and $\mathrm{CE}$ of $24.1 \%$. When the gasoline sale price is dropped to $\$ 0.64 / \mathrm{L}, \mathrm{GE}$ and $\mathrm{CE}$ have equal ROI of $6.8 \%$. Tables 10 and 11 demonstrate the sensitivity of ROI to changes in corn price and cellulosic feedstock price, respectively.

\section{Multiple Decision-Making Perspectives}

As mentioned previously, no single biorefinery option performed best in more than one of the triple bottom line categories (environmental, economic, and social impact). Accordingly, it is important to assess how the weights assigned to the triple bottom line categories affect the outcome of the AHP analysis. To do so, three weighting schemes in addition to the base case were considered. In these additional 
Table 12. Summary of AHP results for four different perspectives.

\begin{tabular}{lcrr}
\hline & GE & CE & FTD \\
\hline Perspective 1: All equal & 0.33 & $\mathbf{0 . 3 5}$ & 0.33 \\
Perspective 2: Environment 2X & 0.30 & $\mathbf{0 . 3 7}$ & 0.33 \\
Perspective 3: Economic 2X & $\mathbf{0 . 3 8}$ & 0.32 & 0.29 \\
Perspective 4: Social 2X & 0.29 & 0.35 & $\mathbf{0 . 3 6}$ \\
\hline
\end{tabular}

schemes, one aspect of the triple bottom line was given a weight of 0.5 and the other two weighted at 0.25 each. Thus, one component of the triple bottom line was given double priority. In the base case, each of the three components had equal weight.

The results of this sensitivity analysis for category weighting indicated that the CE biorefinery was the most sustainable option for two (all equal and environment $2 \times$ ) out of the four decision-making perspectives, and was a very close second for the social $2 \times$ perspective (Table 12 ). For the economic $2 \times$ perspective, GE had the highest score. However, as mentioned previously, the economic performance of GE biorefineries is highly dependent upon corn price, which has been increasing in the recent past, in part due to the growing demand for ethanol. Additionally, the capital costs and operating costs of CE biorefineries will likely decrease as the technology matures.

To further demonstrate the strengths of a triple-bottom-line approach combined with an AHP analysis, we determined the criterion weight required to make a given biorefinery the best overall alternative. Weighting the economic criterion 1.2 times as much as the environmental and social criteria makes GE the most favorable alternative. Similarly, CE is most favorable if the environmental criterion is weighted 0.75 times the other criteria, and FTD is the most favorable if the social criterion is weighted 1.6 times the other criteria.

\section{LIMITATIONS}

In the interest of completeness, it is important to address the limitations of this biorefinery sustainability assessment. First, metrics were assigned values for each biorefinery option based on a thorough review of recent literature. Due to this approach, neither a specific process design nor a specific feedstock was assumed for each biorefinery. The metric values were determined from a variety of different process designs and feedstocks reported in literature. Second, with the exception of the economic calculations, a biorefinery size (fuel production capacity) was not assumed. Thus, an implicit assumption in this analysis is that the values for the environmental and social metrics scale linearly with production. Of course, the AHP framework we provide can easily accommodate more specific follow-up studies that relax such limiting assumptions.

\section{CONCLUSIONS}

This article assessed the sustainability of GE, CE, and FTD biorefineries for liquid fuel production, using the triple bottom line as a guide. Each biorefi- nery was evaluated based on multiple environmental, economic, and social metrics. These metrics were determined from values reported in literature for a variety of different process designs and feedstocks. The Analytic Hierarchy Process was used to analyze this multiobjective, multicriteria problem. The sensitivity of the results to the values and weightings used in the analysis was also considered. Based on the results, CE appears to be modestly more sustainable than GE or FTD for producing renewable liquid fuels. The CE platform combines low environmental impact with moderate economic investment.

\section{NOMENCLATURE}

\begin{tabular}{|c|c|}
\hline AHP & Analytic Hierarchy Process \\
\hline $\mathrm{CE}$ & Cellulosic Ethanol \\
\hline CHP & Combined Heat and Power \\
\hline DDGS & Distillers Dried Grains and Solubles \\
\hline$E_{\text {fossil }}$ & $\begin{array}{l}\text { Ratio of well-to-wheel total fossil fuel } \\
\text { energy input to energy in the biofuel }\end{array}$ \\
\hline$E_{\text {total }}$ & $\begin{array}{l}\text { Ratio of well-to-wheel total energy input } \\
\text { to energy in the biofuel }\end{array}$ \\
\hline E85 & $\begin{array}{l}\text { Fuel mixture of } 85 \% \text { ethanol and } 15 \% \\
\text { gasoline }\end{array}$ \\
\hline FTD & Fischer-Tropsch Diesel \\
\hline FTS & Fischer-Tropsch Synthesis \\
\hline GE & Grain Ethanol \\
\hline GHG & Greenhouse Gas \\
\hline GREET & $\begin{array}{l}\text { Greenhouse gases, Regulated Emissions, } \\
\text { and Energy use in Transportation model }\end{array}$ \\
\hline IPCC & $\begin{array}{l}\text { Intergovernmental Panel on Climate } \\
\text { Change }\end{array}$ \\
\hline LCA & Life-cycle Assessment \\
\hline MLY & Million L/yr \\
\hline $\mathrm{Mg}$ & Megagram \\
\hline $\mathrm{NO}_{\mathrm{x}}$ & Nitrogen Oxides \\
\hline PM-2.5 & $\begin{array}{l}\text { Particulate matter less than } 2.5 \mu \mathrm{m} \text { in di- } \\
\text { ameter }\end{array}$ \\
\hline PM-10 & $\begin{array}{l}\text { Particulate matter less than } 10 \mu \mathrm{m} \text { in di- } \\
\text { ameter }\end{array}$ \\
\hline ROI & Return on Investment \\
\hline $\mathrm{SO}_{\mathrm{x}}$ & Sulfur Oxides \\
\hline SSF & $\begin{array}{l}\text { Simultaneous Saccharification and Fer- } \\
\text { mentation }\end{array}$ \\
\hline VOC & Volatile Organic Compounds \\
\hline WTW & Well-to-Wheel \\
\hline
\end{tabular}

\section{LITERATURE CITED}

1. What is a biorefinery? Biomass Research, National Renewable Energy Laboratory, Department of Energy. Available at: http://www.nrel.gov/biomass/ biorefinery.html. Accessed on March 5, 2009.

2. McAloon, A., Taylor, F., Yee, W., Ibsen, K., \& Wooley, R. (2000). Determining the cost of producing ethanol from corn starch and lignocellulosic feedstocks, Golden, CO: National Renewable Energy Laboratory.

3. United States Environmental Protection Agency. Combined heat and power: An energy-efficient choice for the ethanol industry. Available at: http://www. 
epa.gov/CHP/documents/ethanol_fs.pdf. Accessed on March 10, 2009.

4. Hamelinck, C.N., van Geertje, H., \& Faaij, A. (2005). Ethanol from lignocellulosic biomass: Techno-economic performance in short-, middleand long-term, Biomass and Bioenergy, 28, 384410 .

5. Van der Laan, G.P., \& Beenackers, A. (1999). Kinetics and selectivity of the Fischer-Tropsch synthesis: A literature review, Catalysis Reviews Science and Engineering, 41, 255-318.

6. Faaij, A., van Ree, R., Waldheim, L., Olsson, E., Oudhuis, A., Van Wijk, A., Daey Ouwens, C., \& Turkenburg, W. (1997). Gasification of biomass wastes and residues for electricity production, Biomass and Bioenergy, 12, 387-407.

7. Boerrigter, H., \& den Uil, H. (2002). Green diesel from biomass via Fischer-Tropsch synthesis: New insights in gas cleaning and process design. In Pyrolysis and Gasification of Biomass and Waste Meeting, October 30 to September 1, Strasbourg France.

8. Tijmensen, M.J.A., Faaij, A.P.C., Hamelinck, C.N., \& van Hardeveld, M.R.M. (2002). Exploration of the possibilities for production of Fischer Tropsch liquids and power via biomass gasification, Biomass and Bioenergy, 23, 129-152.

9. Saaty, T.L. (1980). The analytic hierarchy process, New York, NY: McGraw-Hill.

10. Saaty, T.L. (1990). Multicriteria decision making: The analytic hierarchy process, Pittsburgh, PA: RWS Publications.

11. Elkington, J. (1998). Cannibals with Forks: The triple bottom line of the 21st century, Stoney Creek, CT: New Society Publishers.

12. Elkington, J. (2004). Enter the triple bottom line. In A. Henriques \& J. Richardson (Eds.), The triple bottom line: Does it all add up? (pp. 1-16), London, UK: Earthscan.

13. Wang, M., Wu, M., \& Huo, H. (2007). Life-cycle energy and greenhouse gas emission impacts of different corn ethanol plant types, Environmental Research Letters, 2, 024001.

14. Unnasch, S. (2005). Alcohol fuels from biomass: Well-to-wheel energy balance. In International Symposium on Alcohol Fuels, September 28, San Diego, CA.

15. Wang, M., Wu, M., \& Huo, H. (2007). Life-cycle energy and greenhouse gas results of FischerTropsch diesel produced from natural gas, coal, and biomass. In SAE Government/Industry Meeting, May 14-16, Washington, DC.

16. Pimentel, D. (1991). Ethanol fuels: Energy security, economics, and the environment, Journal of Agricultural and Environmental Ethics, 4, 1-13.

17. Pimentel, D. (2002). Limits of biomass utilization. Encyclopedia of physical science and technology (3rd Edition, pp. 159-171), New York: Academic Press.

18. Patzek, T. (2004). Thermodynamics of the cornethanol biofuel cycle, Critcal Reviews in Plant Sciences, 23, 519-567.
19. Pimentel, D., \& Patzek, T. (2005). Ethanol production using corn, switchgrass, and wood; biodiesel production using soybean and sunflower, Natural Resources Research, 14, 65-76.

20. Sheehan, J., Aden, A., Paustian, K., Killian, K., Brenner, J., Walsh, M., \& Nelson, R. (2004). Energy and environmental aspects of using corn stover for fuel ethanol, Journal of Industrial Ecology, 7, 117-146.

21. Morey, R., Tiffany, D., \& Hatfield, D. (2006). Biomass for electricity and process heat at ethanol plants, Applied Engineering in Agriculture, 22, $723-728$.

22. Kim, S., \& Dale, B. (2005). Environmental aspects of ethanol derived from no-tilled corn grain: nonrenewable energy consumption and greenhouse gas emissions, Biomass and Bioenergy, 28, 475489.

23. Wu, M., Wu, Y., \& Wang, M. (2006). Energy and emission benefits of alternative transportation liquid fuels from switchgrass: A fuel life cycle assessment, Biotechnology Progress, 22, 10121024.

24. Jungbluth, N., Frischknecht, R., Emmenegger, M., Steiner, R., \& Tuchschmid, M. (2007). Life-cycle assessment of BTL-fuel production: Life cycle impact assessment and interpretation. Renew: Sustainable energy systems for transport. Available at: http://www.renew-fuel.com/fs_documents. php. Accessed on March 11, 2009.

25. Mueller, S., \& Plevin, R. (2008). Determining climate benefits: Global warming intensity of ethanol, BioCycle Energy, 49, 50.

26. Combined Heat and Power Partnership, United States Environmental Protection Agency. Impact of combined heat and power on energy use and carbon emissions in the dry mill ethanol process. Available at: www.epa.gov/chp/documents/ ethanol_energy_balance.pdf. Accessed on March 10, 2009.

27. Farrel, A., Plevin, R., Turner, B., Jones, A., O'Hare, M., \& Kammen, D. (2006). Ethanol can contribute to energy and environmental goals, Science, 311, 506-508.

28. Wu, M., Wang, M., \& Huo, H. (2006). Fuel-cycle assessment of selected bioethanol production pathways in the United States. Center for Transportation Research, Argonne National Laboratory. Available at: http://www.transportation.anl. gov/pdfs/TA/377.pdf. Accessed on March 4, 2009.

29. Spatari, S., Zhang, Y., \& MacLean, H. (2005). Life cycle assessment of switchgrass- and corn stoverderived ethanol-fueled automobiles, Environmental Science and Technology, 39, 9750-9758.

30. Simpson, T., Sharpley, A., Howarth, R., Paerl, H., \& Mankin, K. (2008). The new gold rush: fueling ethanol production while protecting water quality, Journal of Environmental Quality, 37, 318324.

31. Kim, S., \& Dale, B. (2004). Cumulative energy and global warming impact from the production 
of biomass for biobased products, Journal of Industrial Ecology, 7, 147-162.

32. Patzek, T.W. (2007). A first-law thermodynamic analysis of the corn ethanol cycle, Natural Resources Research, 15, 255-270.

33. Biomass feedstock composition and property database. Biomass program, energy efficiency and renewable energy. U. S. Department of Energy. Available at: http://www1.eere.energy.gov/ biomass/feedstock_databases.html. Accessed on January 29, 2010.

34. Keeney, D., \& Muller, M. (2006). Water use by ethanol plants: Potential challenges, Minneapolis, MN: Institute for Agriculture and Trade Policy.

35. Philips, S., Aden, A., Jechura, J., \& Dayton, D. (2007). Thermochemical ethanol via indirect gasficiation and mixed alcohol synthesis of lignocellulosic biomass, Golden, CO: National Renewable Energy Lab.

36. Pate, R., Hightower, M., Cameron, C., \& Einfeld, W. (2007). Overview of energy-water interdependencies and the emerging energy demands on water resources, Los Alamos, NM: Sandia National Laboratories. Report SAND 2007-1349C.

37. Aden, A., Ruth, M., Ibsen, K., Jechura, J., Neeves, K., Sheehan, J., Wallace, B., Montague, L, Slayton, A., \& Lukas, J. (2002). Lignocellulosic biomass to ethanol process design and economics utilizing co-current dilute acid prehydrolysis and enzymatic hydrolysis for corn stover, Golden, CO: National Renewable Energy Laboratory.

38. Water Science and Technology Board (2008). Water implications of biofuels production in the United States, Washington, D.C.: The National Academies Press.

39. Marano, J., \& Ciferno, J. (2001). Life cycle greenhouse gas emissions inventory for Fischer-
Tropsch fuels, Pittsburg, PA: National Energy Technology Lab.

40. Aden, A. (2007). Water usage for current and future ethanol production, Southwest Hydrology, 6, 22-23.

41. Wright, M., \& Brown, R. (2007). Comparative economics of biorefineries based on the biochemical and thermochemical platform, Biofuels, Bioproducts. and Biorefining, 1, 49-56.

42. Massie, C.T., \& Shukla, A. (2004). Biomass cogeneration plant at Central MN ethanol coop. Sebesta Blomberg \& Associates, Inc. AIChE Conference proceedings, Austin, TX. Available at: http://www. nt.ntnu.no/users/skoge/prost/proceedings/ aiche-2004/pdffiles/papers/035b.pdf. ACcessed on March 4, 2009.

43. Swensen, D. (2008). The economic impact of ethanol production in Iowa. Staff General Research Papers, Department of Economics, Iowa State University. Available at: http://www.econ. iastate.edu/research/webpapers/paper_12865. pdf. Accessed on March 7, 2009.

44. Peters, M., \& Timmerhaus, K. (1990). Plant design and economics for chemical engineers (4th Edition), New York, NY: McGraw Hill.

45. Congress of the United States Congressional Budget Office. (2009). The impact of ethanol use on food prices and greenhouse gas emissions. Available at: http://www.cbo.gov/ftpdocs/100xx/ doc10057/04-08-Ethanol.pdf. Accessed on March 7, 2009.

46. Hill, J., Polasky, S., Nelson, E., Tilman, D., Huo, H., Ludwig, L., Neumann, J., Zheng, H., \& Bonta, D. (2009). Climate change and health costs of air emissions from biofuels and gasoline, Proceedings of National Academy of Sciences of the United States of America, 106, 2077-2082. 